\title{
Study on Evaluation of Space Vitality in Torpoint by Using Analytic Hierarchy Process
}

\author{
Yiming Zhu, Shaojie Shen \\ Soochow University, Suzhou, 215000, China
}

\begin{abstract}
The purpose of this paper is to establish an evaluation system to evaluate space vitality objectively using analytic hierarchy process (AHP). Through an extensive literature review, a preliminary list of evaluation criteria was obtained and used to construct an AHP model. An AHP survey was then conducted with architecture students to calculate the weight of each evaluation factor. Also, the model was applied to Toproint, a small town near Tamar River in UK, to test its applicability and identify the spatial features in the chosen sites.
\end{abstract}

Key words: analytic hierarchy process; space vitality; evaluation; Torpoint

\section{Introduction}

It is widely recognized among architects that urban public space must meet human needs. Urban public space with great vitality can be defined as a safer, more desirable, and more appealing space where more opportunities are provided for social activities and cultural interactions. Evaluation criterion on space quality and vitality have been studied and established, as a result of the heating discussion on urban public space. For instance, Jan Gehl pointed out 12 quality criteria for good design of urban public space and categorized them under three main aspects: protection, comfort and enjoyment. Although several studies have been developed for the evaluation of space quality and vitality, same weaknesses have been identified among them that the evaluation methodologies are limited due to their inability to quantify the intangible criteria and to process the data gathered from investigation. Thus, this article aims to use an analytic hierarchy process (AHP) based method to evaluate space vitality from the perspectives of relevant people's preferences, as well as to analyze the possibility of using AHP as a decision-making tool in the selection of assessment criteria for the space vitality evaluation system. This article has established the following three goals:

(1) To establish an evaluation system to assess space vitality objectively;

(2) To comparatively analyze the importance of each criteria and identify their weights by conducting surveys;

(3) To test the applicability of the system developed in this article by applying it to Torpint, a small town near Tamar River in UK.

\section{Understanding the Field of Enquiry}

2.1 The definition of space vitality

People's public life unfolds in various forms such as walking, shopping, conversation, exercising, festivities and so on. Urban public space is where these activities happen, as Hou noted. It has been considered as a major concern among 
urban planners for centuries since ancient times.

However, forces of modern urbanization have posed increasing threat upon public space. Sense of community and openness has experienced a sharp decline because of the privatization of public space and the existence of consumption space. Moreover, qualities that cities used to have, such as an appropriate street scale, disappeared due to change of design focus from the needs and expectations of pedestrians to the requirements of cars. Lynch defined these needs and expectations of pedestrians as the sources of vitality. The ignorance of them resulted in a negative effect on citizens' daily life.

Lynch, one of the most famous urban planners considered vitality as one of the key aspects of urban design and describes it as the degree to which the places support the functions, biological requirements and capabilities of human beings. Jacobs, an Canadian-American journalist, and activist who influenced urban studies, defined vitality as the interactions between the people on the streets. In her perspective, individual and social life are more important than physical needs in urban planning. Features such as the variety of spatial practices and scheduled activities of a day are signs of urban vitality. Vitality determines the degree to which an urban public space is socially successful.

From the studies of the concept of "vitality" above, we can conclude that vitality is the result of the interaction among people, places, and activities. The characterization of vitality is the continuous activities of the crowd while the physical environment of urban public space itself serves as a carrier for those activities. Different characteristics such as function, traffic, construction intensity and other environmental elements will have different interactive impact upon the amount and duration of people's activities. Therefore, in this article, urban vitality is defined as the capacity of a specific built environment to boost both social and individual activities. To further deconstruct vitality, we need to divide it into two dimensions: characterization (which shows the degree of vitality) and influencing factors. And looking for the metrics of each dimension.

\subsection{Characterization and influencing factors of space vitality}

\subsubsection{Characterization}

Human activities reflect the interaction and participation of human life, which are used to measure the vitality of the city. Human activities can be deconstructed into two interacting elements: population concentration and existing activities. The more intensive human activities, the higher the urban vitality. Studies of identifying appropriate indicators to measure human activities have been done by several researchers and their methods are listed in Table 1.

Table 1. Studies of identifying appropriate indicators to measure human activities

\begin{tabular}{|c|c|c|}
\hline Article & Indicators of vitality & Methods of measurement \\
\hline $\begin{array}{l}\text { Quantitative analysis of the city square } \\
\text { dynamic space elements }\end{array}$ & $\begin{array}{l}\text { Number of activities Number of } \\
\text { people }\end{array}$ & $\begin{array}{l}\text { Observation and record within a certain } \\
\text { period }\end{array}$ \\
\hline $\begin{array}{l}\text { Quantitative evaluation on street } \\
\text { vibrancy and its impact factors: A case } \\
\text { study of Chengdu }\end{array}$ & Population density & $\begin{array}{l}\text { ArcGIS } \\
\text { Mobile Phone Signaling Data }\end{array}$ \\
\hline $\begin{array}{c}\text { The analysis and Influence Mechanism } \\
\text { Research of Urban Vigorous Space } \\
\text { Based on Multiple Big Data }\end{array}$ & $\begin{array}{l}\text { Population density } \\
\text { Types of activities }\end{array}$ & $\begin{array}{c}\text { Heatmap Data } \\
\text { ArcGIS }\end{array}$ \\
\hline
\end{tabular}

2.2.2Influencing factors of space vitality

The physical environment, which is identified as the influencing factors in the context, can be regarded as the groundwork for urban vitality. It refers to man-made surroundings that provide spaces for everyday human activities. 
Physical environment includes the physical factors ranging from the visual pleasure and displeasure in the overall space to the accessibility via private or public transport. For example, the coexistence of ancient and modern architecture is representative of cultural diversity, which may contribute to the formation of an urban environment that is rich in cultural appeal, thus to promote the concentration of human flow. A pedestrian street provides more opportunities for citizens' daily social contact and interactions. Meanwhile, the criteria of public spaces with great vitality have been recognized and researched on for some time. The researchers and their main achievements are listed in Table 2.

Table 2. Findings in the criteria of public spaces with great vitality

\begin{tabular}{|c|c|}
\hline Name & Findings \\
\hline Jan Gehl & $\begin{array}{l}12 \text { quality criteria for good design of public open spaces, which were categorized under three } \\
\text { main themes: protection, comfort and enjoyment }\end{array}$ \\
\hline Ewing\& Clemente & $\begin{array}{l}5 \text { intangible qualities of urban design that are applied to streets: imageability, visual enclosure, } \\
\text { human scale, transparency and complexity }\end{array}$ \\
\hline Mehta & $\begin{array}{l}5 \text { dimensions of public spaces for evaluating the quality: inclusiveness, meaningfulness, } \\
\text { safety, comfort and pleasure }\end{array}$ \\
\hline $\begin{array}{c}\text { Carmona \& De } \\
\text { Magalhaes }\end{array}$ & $\begin{array}{l}\text { defects in regulations for the users; inappropriate method of maintenance; lack of investments } \\
\text { into and on-going resourcing of public space; lack of coordination among stakeholders }\end{array}$ \\
\hline
\end{tabular}

The results of the case studies and literature review above were reclassified and sorted, and 23 influencing factors were thus identified and categorized into 6 dimensions. These six dimensions of factors are entitled as safety and protection, accessibility, maintenance, enjoyment, attractiveness and inclusiveness, as Table 3 shows.

Table 3. Influencing factors of space vitality

\begin{tabular}{|c|c|c|c|c|c|}
\hline Safety and Protection & Accessibility & Maintenance & Enjoyment & Attractiveness & Inclusiveness \\
\hline $\begin{array}{l}\text { Availability of information/ } \\
\text { complaint center }\end{array}$ & Location & $\begin{array}{l}\text { Management of litter and } \\
\text { filth }\end{array}$ & $\begin{array}{c}\text { Presence and } \\
\text { condition of public } \\
\text { facilities and } \\
\text { amenities }\end{array}$ & $\begin{array}{c}\text { Good design/ } \\
\text { detailing of space or } \\
\text { landscape }\end{array}$ & $\begin{array}{l}\text { Used by all, irrespective } \\
\text { of race, age, gender }\end{array}$ \\
\hline $\begin{array}{l}\text { Presence of adequate } \\
\text { illumination during night } \\
\text { time }\end{array}$ & $\begin{array}{l}\text { Accessibility via } \\
\text { transport }\end{array}$ & $\begin{array}{c}\text { Condition of } \\
\text { infrastructure and } \\
\text { buildings }\end{array}$ & $\begin{array}{c}\text { Possibilities for sitting } \\
\text { and walking }\end{array}$ & $\begin{array}{l}\text { Presence, quality and } \\
\text { condition of public art }\end{array}$ & \\
\hline $\begin{array}{c}\text { Protection against unpleasant } \\
\text { sense experience like wind, } \\
\text { dust or pollution }\end{array}$ & $\begin{array}{c}\text { Ease of } \\
\text { movement in and } \\
\text { out }\end{array}$ & Condition of green areas & $\begin{array}{c}\text { Sense of privacy and } \\
\text { enclosure }\end{array}$ & $\begin{array}{l}\text { Uncluttered view of } \\
\text { the space }\end{array}$ & \\
\hline Surveillance measures & $\begin{array}{l}\text { Density of roads } \\
\text { inside }\end{array}$ & & $\begin{array}{l}\text { Suitable scale and size } \\
\text { for movements and } \\
\text { behavior in human } \\
\text { dimension }\end{array}$ & $\begin{array}{l}\text { Richness of activities } \\
\text { provided for citizens }\end{array}$ & \\
\hline \multirow[t]{2}{*}{ Absence of vehicles } & & & $\begin{array}{l}\text { Pleasant micro- } \\
\text { climate }\end{array}$ & & \\
\hline & & & $\begin{array}{l}\text { Provision of buffer } \\
\text { from traffic nuisance }\end{array}$ & & \\
\hline
\end{tabular}

\subsection{Evaluation of space vitality}

Both the characterization and influencing factors can be used to evaluate the space vitality. In the former way, people can intuitively judge whether the area is frequently used and vibrant by investigating the population density, number of activities within a certain period. However, through this method, people only get a simple date, rather than carrying out a 
deeper analysis of the formation of vitality in the space.

In the latter approach, advantages/disadvantages can be revealed by applying influencing factors as the criteria and sub-criteria of quality design, according to Hickman's suggestion that evaluation should be able to demonstrate the strengths and weaknesses of the object. Normally, evaluation methods in architecture neglect the relative superiority and inferiority of criteria alternatives relative to each other, and the absence of numerical data for comparative analysis may be identified as the major barriers. The degree of importance of different evaluation criteria varies, and there is a hierarchy among them according to which each criterion gets its own weight. Assigning weights depends on the way in which a public space is expected to perform in any particular dimension from the users' perspectives, which makes it a crucial part of the evaluation process.

Among the alternatives, although there are conflicts with each other, the one with the highest fitness will be selected, so that the specific objectives can be met. This process is the Multi Criteria Decision Making Method. This decision-making process will involve many people, and some measurable and unmeasurable factors can be evaluated in the process of participation, and this decision-making process is a very famous analysis method and decision support system. Therefore, when revealing the standard of priority definition, the goal is satisfied through the pair-wise comparison and the multi-level and multi-objective decision model. In this process, MCDM method is used, which is a meaningful way to measure tangible things. When measuring tangible things first, MCDM method can achieve the final decision-making and evaluation. when we use it as an evaluation, we can contact when we estimate it, and we can also deal with intangible standards when we compare it. Using this method can help and support our work.

By evaluating the vitality of space and some application indicators, this method has been widely used in MCDM applications, which belongs to the AHP. When building a framework for decision-making problems, we can have a more rational and comprehensive framework through analytic hierarchy process, which is mainly based on these premises. The quantitative factors and their problem representatives include tangible assets, intangible assets, etc., which can be used as the overall goal of this assessment element, which belongs to the assessment alternative scheme.

2.4 Analytic hierarchy process (AHP)

Using hierarchical structure to make complex decision-making model, Thomas L. Saaty made assumptions and put forward the AHP. Pairwise comparison of priority values is based on the measurement theory of generated elements, and belongs to AHP method. The system can identify the problem by decomposing it into tiny integer bits, then compare two elements, and comprehensively compare and identify their cross significance and the size of this significance. Therefore, when analyzing complex problems with multiple subjective criteria qualitatively and quantitatively, AHP is very helpful to decision makers.

The AHP involves the following basic steps:

(1) Hierarchical AHP model is built by hierarchical factors and problem criteria.

(2) The measurement results of the weight and priority of each element are evaluated by the method of pairwise comparison.

(3) The choice of the best alternative will be determined through the comprehensive evaluation of the priority of each weight standard. Comprehensive rating is based on the premise of the above priority comparison.

Therefore, this kind of application has been used in various decision-making problems in many fields such as architecture, resource allocation, economy, project selection, health, computer technology, energy policy, planning, marketing and so on. 


\section{Methodology}

The overall research process is presented in Table 4, and the following sub- chapters describe each stage in detail.

Table 4. Research process

\begin{tabular}{c|c|c}
\hline Stage & Purpose & Methodology \\
\hline Stage 1 & Defining evaluation criteria & Deriving evaluation criteria through literature review and case study \\
\hline Stage 2 & $\begin{array}{c}\text { Identifying the weights of } \\
\text { criteria through AHP method }\end{array}$ & $\begin{array}{c}\text { 1. Developing an AHP model. } \\
\text { 2. Conducting AHP survey and calculating to determine the weight of } \\
\text { each criterion. }\end{array}$ \\
\hline Stage 3 & $\begin{array}{c}\text { Applying the model to } \\
\text { project2B proposal }\end{array}$ & $\begin{array}{c}\text { Testing the applicability of the system by evaluating 5 different sites } \\
\text { in Torpoint. }\end{array}$ \\
\hline
\end{tabular}

\subsection{Stage 1: defining evaluation criteria}

In order to identify the initial set of evaluation criteria, an extensive review of precedent studies and previous assessment tools related to space vitality was undertaken. A variety of elements concerning safety, accessibility and other aspects were derived and hierarchically structured in Figure 1.

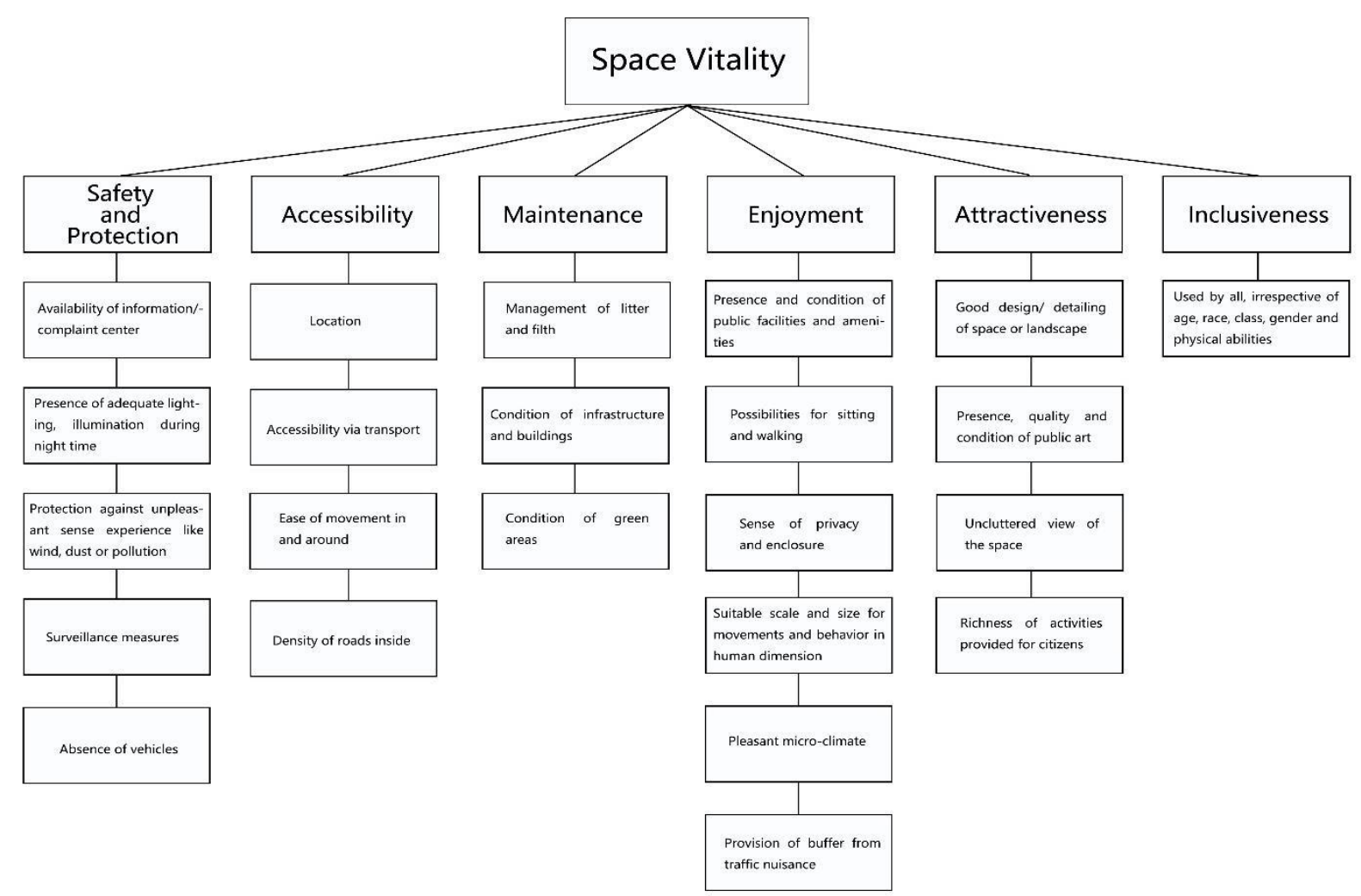

Figure 1. Hierarchical structure of evaluation criteria

\subsection{Stage 2: identifying the weights of criteria through AHP method}

Relative weights or the priority value of each element (criteria, sub-criteria) at different levels of the hierarchy should be determined when the decision hierarchy is created. According to the structure of AHP hierarchy pairwise comparison matrix, a questionnaire containing a total of six pairwise comparison matrix was prepared for the interviewees; 1 for the main criterion, 5 for the sub-criteria. The questionnaire was filled by the interviewees individually. In the questionnaire, the interviewee is asked to make a judgement on the relative importance of evaluation criteria by answering questions like 
"which element is preferred more (is more important) when element 1 and element 2 are compared" and "what is degree of preference of the more preferred element compared to the other?"

The results of these comparisons are arranged in matrix form. The prioritization scale developed by Saaty used to convert the results of such pairwise comparisons in the matrix into numerical values is presented in the table below. Table 5 shows numerical values suggested for preferences expressed by the person undertaking the pairwise comparisons. This scale is employed to construct the pairwise comparisons matrix. As part of the survey, a sample questionnaire prepared for evaluation of the main criteria is provided in Table 6.

Table 5. AHP pairwise comparison scale

\begin{tabular}{c|c}
\hline Numerical Value & Preferences \\
\hline 1 & Equal importance (Preference) \\
\hline 3 & Partial Preference \\
\hline 5 & Essential or strong importance \\
\hline 7 & Demonstrated importance \\
\hline 9 & Absolute Preference \\
\hline $2,4,6,8$ & Intermediate values between two adjacent judgments \\
\hline
\end{tabular}

Table 6. Sample of pairwise comparison matrix for main criteria

\begin{tabular}{|c|c|c|c|c|c|c|}
\hline & $\begin{array}{c}\text { Safety\& } \\
\text { Protection }\end{array}$ & Accessibility & Maintenance & Enjoyment & Attractiveness & Inclusiveness \\
\hline Safety \& Protection & & $3 / 1$ & $2 / 1$ & 1 & $2 / 1$ & $4 / 1$ \\
\hline Accessibility & & & $2 / 1$ & $1 / 3$ & $1 / 2$ & $2 / 1$ \\
\hline Maintenance & & & & $1 / 2$ & 1 & $3 / 1$ \\
\hline Enjoyment & & & & & $2 / 1$ & $4 / 1$ \\
\hline Attractiveness & & & & & & $4 / 1$ \\
\hline Inclusiveness & & & & & & \\
\hline
\end{tabular}

Pairwise comparisons matrices are used to calculate the priority values. During this calculation process, consistency of pairwise comparison judgement should be considered. Because while the significance or priority values of elements are calculated on the basis of the pairwise comparisons matrix in the AHP method, mistakes may occur since pairwise comparisons are based on subjective considerations. To measure this condition, the "Consistency Ratio (CR)" is employed in the method. Judgement of the decision maker is fully consistent if this ratio is zero. When this ratio is close to 1.00 , it can be considered that the pairwise comparison matrix based on judgement of interviewees is un-rational and inconsistent, but random. In addition, a consistency ratio of 0.10 or less indicates that the results are within the acceptable range. All the calculating is conducted in the software called "Yaahp".

\subsection{Stage 3: applying the model to Torpoint to test the applicability of it}

The applicability of the developed evaluation system was tested by assessing the site's space vitality. The chosen site, Torpoint, is located at the intersection of Tamar river and the ocean in UK. Such a unique geographic location has formed its coastline that stretches for several kilometers. However, due to the negligence of the management of the coast, lands that could be used as coastal landscapes were abandoned where silt accumulated. Lacking vitality is obviously a major problem in this area. 
For the evaluation, the scores of each criterion identified in the chosen site were rated on a 5-point Likert scale by students who had participated in the project or been to Torpoint. Previously derived weights were also considered, which would be multiplied by the initial scores to get the final accurate result. Five public spaces with certain amounts of infrastructures were chosen, as Figure 2 shows. Also, a sample questionnaire prepared for the marking of each site is provided in Table 7.

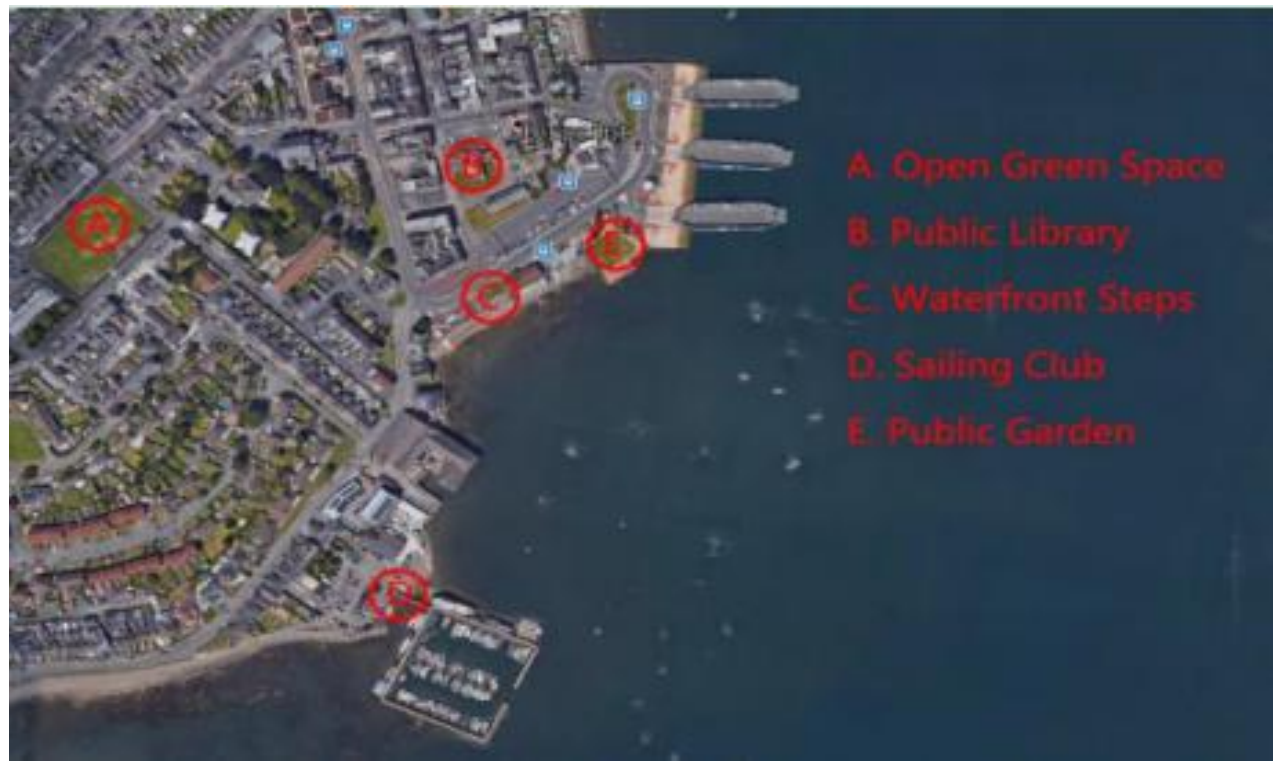

Figure 2. 5 sites in Torpoint

Table 7. Sample questionnaire prepared for the marking of each site

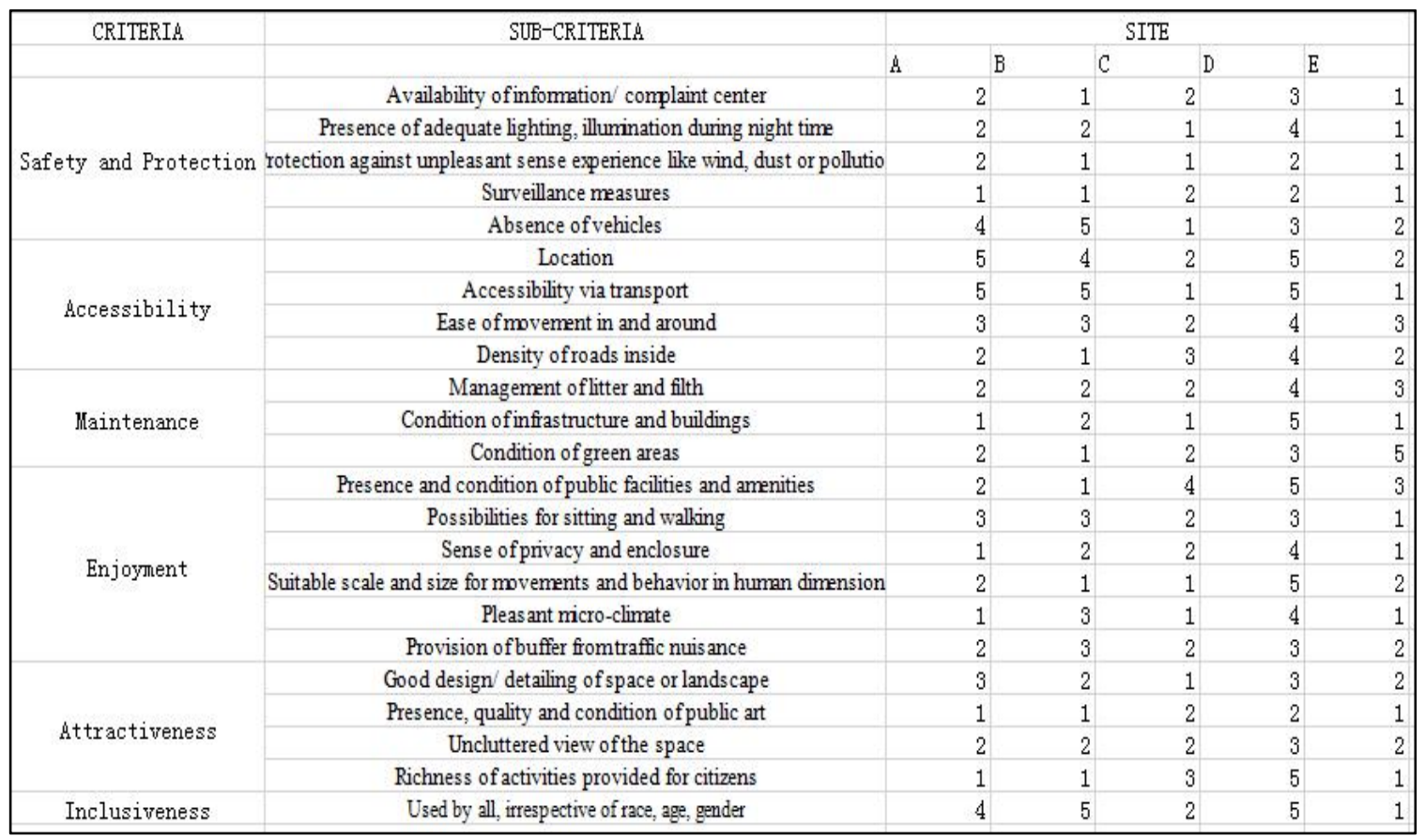




\section{Result}

4.1 The relative importance of evaluation criteria

Table 8. Weights of the criteria and sub-criteria

\begin{tabular}{|c|c|c|c|}
\hline Criteria & Weight & Sub-criteria & Weight \\
\hline \multirow{5}{*}{ Safety and Protection } & \multirow{5}{*}{0.1848} & Availability of information/ complaint center & 0.0447 \\
\hline & & Presence of adequate lighting, illumination during night time & 0.0334 \\
\hline & & Protection against unpleasant sense experience like wind, dust or pollution & 0.0441 \\
\hline & & Surveillance measures & 0.041 \\
\hline & & Absence of vehicles & 0.0217 \\
\hline \multirow{4}{*}{ Accessibility } & \multirow{4}{*}{0.0806} & Location & 0.0227 \\
\hline & & Accessibility via transport & 0.0273 \\
\hline & & Ease of movement in and around & 0.0205 \\
\hline & & Density of roads inside & 0.01 \\
\hline \multirow{3}{*}{ Maintenance } & \multirow{3}{*}{0.1195} & Management of litter and filth & 0.0295 \\
\hline & & Condition of infrastructure and buildings & 0.0366 \\
\hline & & Condition of green areas & 0.0534 \\
\hline \multirow{6}{*}{ Enjoyment } & \multirow{6}{*}{0.1226} & Presence and condition of public facilities and amenities & 0.0159 \\
\hline & & Possibilities for sitting and walking & 0.0173 \\
\hline & & Sense of privacy and enclosure & 0.0172 \\
\hline & & Suitable scale and size for movements and behavior in human dimension & 0.0245 \\
\hline & & Pleasant micro-climate & 0.0271 \\
\hline & & Provision of buffer from traffic nuisance & 0.0205 \\
\hline \multirow{4}{*}{ Attractiveness } & \multirow{4}{*}{0.2455} & Good design/ detailing of space or landscape & 0.0884 \\
\hline & & Presence, quality and condition of public art & 0.0378 \\
\hline & & Uncluttered view of the space & 0.0295 \\
\hline & & Richness of activities provided for citizens & 0.0899 \\
\hline Inclusiveness & 0.2469 & Used by all, irrespective of race, age, gender & 0.2469 \\
\hline
\end{tabular}

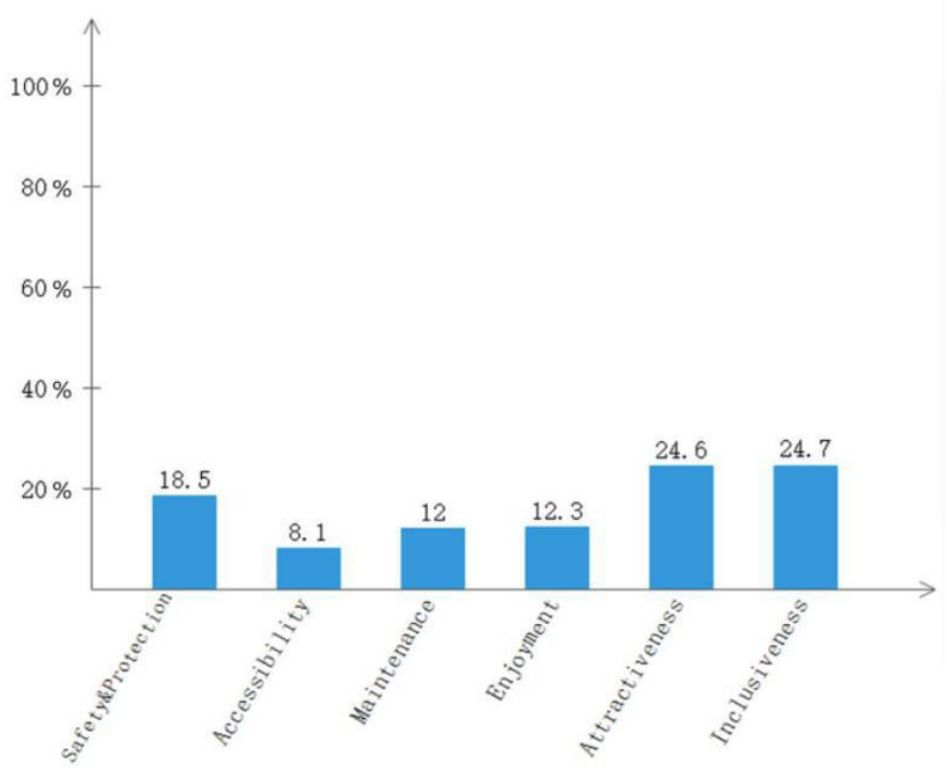

Figure 3. Weights of the main criteria

With respect to the results of the weights of the six criteria, "inclusiveness" ranked as the most important factor of space vitality, representing of about $24.7 \%$ of the total, followed by "attractiveness" which weighs about $24.6 \%$. The weights of these two criteria represent almost $50 \%$ of the total. The weights of the "safety and protection" and "enjoyment" were $18.5 \%$ and $12.3 \%$ respectively. "maintenance" and "accessibility" were evaluated as having relatively low importance. With regard to the "attractiveness" category, "richness of activities provided for citizens" (0.0899) was found to be the most important, followed by "good design/ detailing of space or landscape" (0.0884), "presence, quality and condition of public art" (0.0378), and "uncluttered view of the space" (0.0295). Within the "safety and protection" category, "availability of information/complaint center" (0.0447) was found to be the most important, followed by 
“protection against unpleasant sense experience like wind, dust or pollution" (0.0441) and "surveillance measures" (0.041). "presence of adequate lighting, illumination during night time" (0.0334) and "absence of vehicles" (0.0217) were evaluated as having relatively low importance. "Pleasant micro-climate" (0.0271) was evaluated as having higher importance within the "enjoyment" category than "suitable scale and size for movements and behavior in human dimension" (0.0245), "provision of buffer from traffic nuisance" (0.0205), "possibilities for sitting and walking” (0.0173), "sense of privacy and enclosure" (0.0172) and "presence and condition of public facilities and amenities" (0.0159). Among the items in the "maintenance" category, "condition of green areas" (0.0534) had a considerably higher weight than "condition of infrastructure and buildings" (0.0366) and "management of litter and filth" (0.0295), emphasizing the importance of preserving green spaces. Within the "accessibility" category, "accessibility via transport" (0.0273) had a higher weight than "location" (0.0227) and "ease of movement in and around" $(0.0205)$. The item of "density of roads inside" (0.01) had the lowest weight.

According to the above data results, we can draw the following conclusions:

(1) Inclusiveness is considered a prerequisite for the existence of a public place. If a place is closed to certain people for a variety of reasons or even discriminations towards races, gender, the meaning of "public" would disappear.

(2) People are more concerned with the abundance of activities the space provides than the space itself.

(3) Whether the space can provide security for people is also one of the important assessment criteria.

Therefore, priorities might be given to these aspects when designing urban public space to boost space vitality.

4.2 Application of the space vitality assessment model to Torpoint

Table 9. Scores of the five sites

\begin{tabular}{|c|c|c|c|c|c|c|}
\hline \multirow{2}{*}{ CRITERIA } & \multirow[t]{2}{*}{ SUB-CRITERIA } & \multicolumn{5}{|c|}{ AVERAGE SCORE } \\
\hline & & A & $B$ & c & D & E \\
\hline \multirow{6}{*}{ Safety and Protection } & Availability of information/ complaint center & 1.01 & 1.01 & 0.89 & 1.68 & 1.34 \\
\hline & Presence of adequate lighting, illumination during night time & 0.75 & 1.00 & 0.67 & 1.17 & 1.00 \\
\hline & Protection against unpleasant sense experience like wind, dust or pollution & 1.10 & 0.99 & 0.88 & 1.32 & 0.99 \\
\hline & Surveillance measures & 1.13 & 0.92 & 1.13 & 1.23 & 1.03 \\
\hline & Absence of vehicles & 0.71 & 0.65 & 0.49 & 0.54 & 0.60 \\
\hline & Total 1 & 4.69 & 4.57 & 4.06 & 5.94 & 4.96 \\
\hline \multirow{5}{*}{ Accessibility } & Location & 0.85 & 0.79 & 0.51 & 1.02 & 0.74 \\
\hline & Accessibility via transport & 0.82 & 1.02 & 0.48 & 1.09 & 0.68 \\
\hline & Ease of movement in and around & 0.56 & 0.56 & 0.41 & 0.77 & 0.46 \\
\hline & Density of roads inside & 0.25 & 0.25 & 0.28 & 0.35 & 0.28 \\
\hline & Total 2 & 2.48 & 2.63 & 1.67 & 3.23 & 2.16 \\
\hline \multirow{4}{*}{ Maintenance } & Management of litter and filth & 0.59 & 0.74 & 0.44 & 1.11 & 0.89 \\
\hline & Condition of infrastructure and buildings & 0.92 & 0.82 & 0.55 & 1.28 & 0.92 \\
\hline & Condition of green areas & 1.34 & 1.34 & 0.80 & 1.87 & 2.14 \\
\hline & Total 3 & 2.84 & 2.90 & 1.79 & 4.26 & 3.94 \\
\hline \multirow{7}{*}{ Enjoyment } & Presence and condition of public facilities and amenities & 0.44 & 0.36 & 0.36 & 0.64 & 0.56 \\
\hline & Possibalities for sitting and wallking & 0.43 & 0.48 & 0.22 & 0.56 & 0.52 \\
\hline & Sense of privacy and enclosure & 0.43 & 0.47 & 0.34 & 0.47 & 0.47 \\
\hline & Suitable scale and size for movements and behavior in buman dimension & 0.55 & 0.55 & 0.55 & 0.86 & 0.74 \\
\hline & Pleasant micro-climate & 0.41 & 0.81 & 0.34 & 0.88 & 0.68 \\
\hline & Provision of buffer from traffic nuisance & 0.46 & 0.51 & 0.51 & 0.77 & 0.51 \\
\hline & Total 4 & 2.72 & 3.18 & 2.32 & 4.18 & 3.47 \\
\hline \multirow{5}{*}{ Attractiveness } & Good design detailing of space or landscape & 2.21 & 2.43 & 1.77 & 3.54 & 2.65 \\
\hline & Presence, quality and condition of public art & 0.66 & 0.85 & 0.85 & 1.04 & 0.76 \\
\hline & Uncluttered view of the space & 0.96 & 0.74 & 0.59 & 1.03 & 0.89 \\
\hline & Richness of activities provided for citizens & 2.02 & 2.02 & 3.15 & 3.82 & 2.70 \\
\hline & Total 5 & 5.85 & 6.04 & 6.36 & 9.43 & 6.99 \\
\hline \multirow[t]{2}{*}{ Inclusireness } & Used by all, intespective of race, are, gender & 8.02 & 6.79 & 4.94 & 8.64 & 8.64 \\
\hline & TOTAL & 26.61 & 26.12 & 21.14 & 35.68 & 30.15 \\
\hline
\end{tabular}

Table 9 shows the results of applying the weightings derived from the AHP to the five sites in Torpoint. The AHP weightings were multiplied by mean scores for each item, and to make the numbers easier to understand, the results were 
multiplied by 10 . Total weighted point of each site was $26.61,26.12,21.14,35.68$ and 30.15 . There was also a big difference among criteria and sub-criteria within a single project.

Site D obtained higher scores than the other four sites as site $\mathrm{C}$ obtained the lowest. It shows that the most vigorous area around Torpoint is the sailing club, as the space around the waterfront steps turned out to be the worst and need to be renewed first.The following is a summary of the advantages and disadvantages of each site and the improvement plan based on the calculation results.

Table 10. Advantages and disadvantages of the sites identified through AHP model

\begin{tabular}{|c|c|c|}
\hline Site & Advantages & Disadvantages \\
\hline A & $\begin{array}{l}\text { 1. Good condition of green area, infrastructure } \\
\text { and buildings } \\
\text { 2. Uncluttered view of the space }\end{array}$ & $\begin{array}{l}\text { 1. Absence of adequate lighting during nighttime } \\
\text { 2. No provision of buffer from traffic nuisance }\end{array}$ \\
\hline B & $\begin{array}{l}\text { 1. Easy access via transport } \\
\text { 2. Good sense of privacy and enclosure }\end{array}$ & $\begin{array}{l}\text { 1. No enough surveillance measures } \\
\text { 2. Absence of public facilities } \\
\text { 3. Absence of public art around the library }\end{array}$ \\
\hline $\mathrm{C}$ & $\begin{array}{l}\text { 1. Good location which is close to the water } \\
\text { 2. Great potential to be exploited }\end{array}$ & $\begin{array}{l}\text { 1. No access to the water } \\
\text { 2. No possibility for sitting and walking around } \\
\text { 3. Terrible management of infrastructure and } \\
\text { litter }\end{array}$ \\
\hline D & $\begin{array}{l}\text { 1. Good design of the whole space } \\
\text { 2. Richness of activities provided for citizens } \\
\text { 3. Easy to move in and around } \\
\text { 4. Presence of the information center }\end{array}$ & $\begin{array}{l}\text { 1. Plenty of vehicles that might influence the } \\
\text { safety of pedestrian } \\
\text { 2. No enough green space }\end{array}$ \\
\hline $\mathrm{E}$ & $\begin{array}{l}\text { 1. Close to the ferry station } \\
\text { 2. Suitable scale for people to stay } \\
\text { 3. Enough space for sitting and walking }\end{array}$ & 1. No protection against wind or rain \\
\hline
\end{tabular}

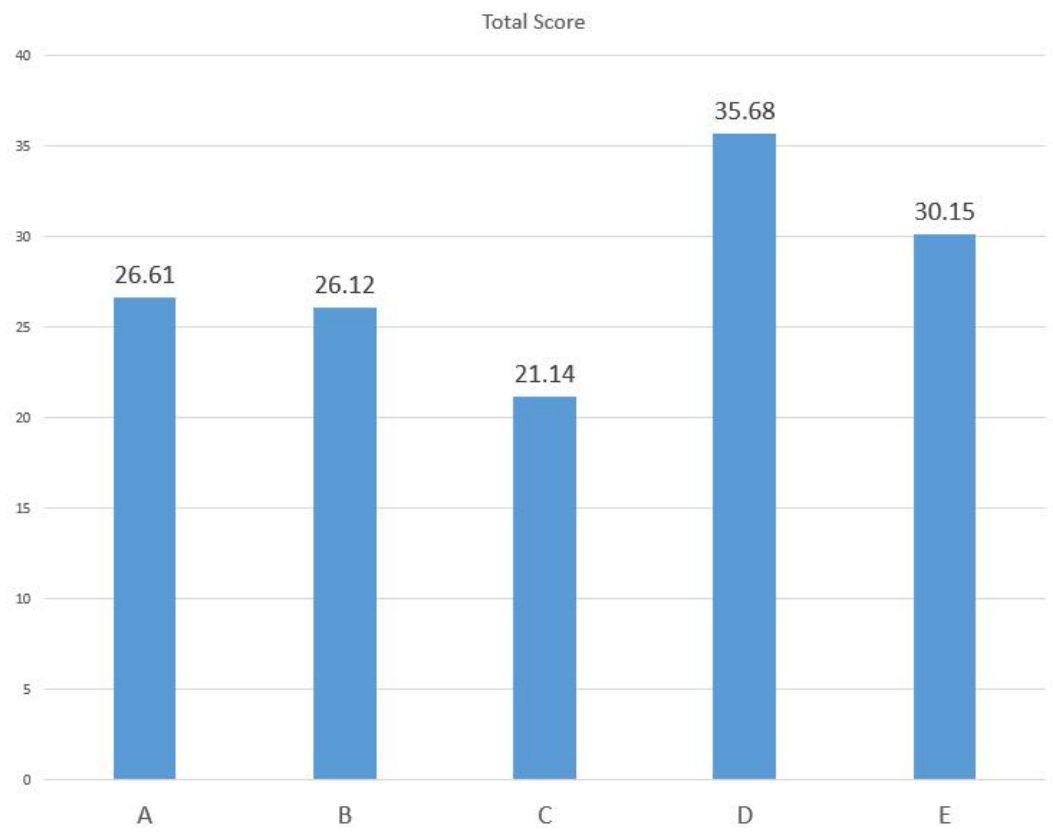

Fingure 4. Scores of the five sites 
Table 11. Advice for improvement

\begin{tabular}{|c|c|}
\hline Site & Advice for improvement \\
\hline A & $\begin{array}{l}\text { 1. Some recreational measures can be added, but at the same time, safety measures should be in place. } \\
\text { 2. Make some space at the edge of the site as a buffer from outside traffic. }\end{array}$ \\
\hline B & $\begin{array}{l}\text { 1. Invite local artists to do artistic creation in the area. } \\
\text { 2. Add public facilities like seats, street lamps or even an ornamental fountain. }\end{array}$ \\
\hline $\mathrm{C}$ & $\begin{array}{l}\text { 1. Garbage and silt need to be removed in time to ensure that people have enough space to move around. } \\
\text { 2. Increase the width of some steps so that people can sit directly on them, as well as use it as a connection } \\
\text { between the beach and the land. } \\
\text { 3. A waterfront platform can be constructed to bring people closer to the water. }\end{array}$ \\
\hline $\mathrm{D}$ & $\begin{array}{l}\text { 1. Distinguish traffic routes and pedestrian routes inside strictly. } \\
\text { 2. Plan some areas as green space. }\end{array}$ \\
\hline $\mathrm{E}$ & $\begin{array}{l}\text { 1. Plant trees to provide protection against unpleasant sense experience as well as add the green space. } \\
\qquad \text { 2. The railings need to be repaired to ensure safety. }\end{array}$ \\
\hline
\end{tabular}

\section{Conclusions}

Urban public space is the basic unit of urban planning, construction and management, and an important embodiment of vitality. The design of urban public space is actually the design of city life, which aims to provide interactive activities for urban residents. This paper constructs a relatively comprehensive space vitality evaluation system using analytic hierarchy process. In the research procedure, methods like case study, literature review, interview and site investigation were applied. Evaluation criteria and sub-criteria were thus determined, such as safety and protection, attractiveness, enjoyment and so on. Then the weight of each criterion was derived by using AHP method and conducting interviews with relevant people to complete the evaluation system, which were later applied to Torpoint. The system performed well and the scores of the five chosen sites were calculated, which provided a basis for the later suggestions of renewal. Furthermore, in order to analyze the internal mechanism of vitality formation, a detailed investigation of crowd activities on the site, including population density and activity types will need to be conducted. The two dimensions of space vitality, characterization and influencing factors will be put together to study the correlation between them using mathematical analysis software like SPSS. In this way, we will have a better understanding of space vitality and promote our urban design strategy.

\section{Conflicts of Interest}

The author declares no conflicts of interest regarding the publication of this paper.

\section{References}

[1] Baj̧̧inovci B., Gjinolli I. and Beqiri R. (2018). Measuring Vitality of the Ottoman Public Space in Kosovo Cities. Journal of Science, Humanities and Arts - JOSHA, 5(4): 10-11.

[2] Hou J. (2010). (Not) Your Everyday Public Space. Insurgent Public Space: Guerilla Urbanism and the Remaking of Contemporary Cities. Routledge, New York.

[3] Jalaladdini S. and Oktay D. (2012). Urban Public Spaces and Vitality: A Socio-Spatial Analysis in the Streets of Cypriot Towns. Procedia - Social and Behavioral Sciences, (35): 664-674. 
[4] Taylor M. (2003). Public Policy in the Community. Palgrave Macmillan, New York.

[5] Işiklar S. (2017). Vitality of the Cities. International Journal of Architectural Engineering Technology, 4(1): 18-23.

[6] Lynch K. (1971). The Image of the City. the MIT Press, Cambridge Mass.

[7] Montgomery J. (1998). Making a City: Urbanity, Vitality and Urban Design. Journal of Urban Design, 3(1): 93-116.

[8] Jacobs J. (2015). The Death and Life of Great American Cities (Büyük Amerikan Şehirlerinin Ölümü ve Yaşamı), 2th ed. İstanbul, Metis.

[9] Jin X., Long Y., Sun W., Lu Y., Yang X. and Tang J. (2017). Evaluating Cities' Vitality and Identifying Ghost Cities in China with Emerging Geographical Data. Cities 2017, (63): 98-109.

[10] Yue W., Chen Y., Zhang Q. and Liu, Y. (2019). Spatial Explicit Assessment of Urban Vitality Using Multi-Source Data: A Case of Shanghai, China. Sustainability, 11(3): 638.

[11] Gehl J. and Koch J. (2011). Life between Buildings. Island Press, London.

[12] Ewing R. and Clemente O. (2013). Measuring Urban Design: Metrics for livable places. Island Press.

[13] Mehta V. (2013). The Street: a Quintessential Social Public Space. Routledge

[14] Carmona M. and De Magalhaes C. (2006). Public Space Management: Present and Potential. Journal of Environmental Planning and Management, 49(1): 75-99.

[15] Hickman R. (2015). Assessment in Art and Design Education: Further Reflections upon Whippet-fancying and Procrustes. Visual Inquiry, 4(1): 23-31. 